\title{
Cytotoxic performances of new anionic cyclometalated Pt(II) complexes bearing chelated $\mathrm{O}^{\wedge} \mathrm{O}$ ligands
}

Andreea Ionescu, ${ }^{* a, b}$ Rossella Caligiuri, ${ }^{a}$ Nicolas Godbert, ${ }^{\mathrm{a}, \mathrm{b}}$ Loredana Ricciardi, ${ }^{\mathrm{b}}$ Massimo La Deda, ${ }^{\mathrm{a}, \mathrm{b}}$ Mauro Ghedini, ${ }^{\mathrm{a}, \mathrm{b}}$ Nicola Ferri, ${ }^{\mathrm{c}}$ Maria Giovanna Lupo, ${ }^{\mathrm{c}}$ Giorgio Facchetti, ${ }^{\mathrm{d}}$ Isabella Rimoldi ${ }^{\mathrm{d}}$, Iolinda Aiello*a,b

a. MAT-InLAB, LASCAMM CR-INSTM, Unità INSTM della Calabria,Dipartimento di Chimica e Tecnologie Chimiche, Università della Calabria, Ponte Pietro Bucci Cubo 14C, 87036 Arcavacatadi Rende (CS), Italy; e-mail: andreea.ionescu@unical.it, iolinda.aiello@unical.it

b. CNR NANOTEC-Istituto di Nanotecnologia U.O.S. Cosenza, 87036 Arcavacata di Rende (CS), Italy

c. Università degli Studi di Padova, Dipartimento di Scienze del Farmaco, Via Marzolo 5, 35131, Padua, Italy.

d. Università degli Studi di Milano, Dipartimento di Scienze Farmaceutiche, Via Venezian 21, 20133 Milan, Italy.

The in vitro biological activity on the MDA-MB-231 triple-negative breast cancer (TNBC) cell line of two different series of anionic Pt(II) organometallic complexes was tested. For the first time, the cytotoxic activity of anionic $\mathrm{Pt}(\mathrm{II})$ complexes has been observed. The anionic compounds of general formula $\mathrm{NBu}_{4}\left[\left(\mathrm{C}^{\wedge} \mathrm{N}\right) \mathrm{Pt}\left(\mathrm{O}^{\wedge} \mathrm{O}\right)\right]$, where $\left(\mathrm{C}^{\wedge} \mathrm{N}\right)$ stands for the cyclometalated form of 2-phenylpyridine $(\mathrm{H}(\mathrm{PhPy}))$, 2-thienylpyridine $(\mathrm{H}(\mathrm{Thpy}))$ or 2-benzo[h]quinoline $(\mathrm{H}(\mathrm{Bzq}))$ feature two different $\left(\mathrm{O}^{\wedge} \mathrm{O}\right)$ chelated ligands: the tetrabromocatechol $[\mathrm{BrCat}]^{2-}(\mathbf{1 - 3})$ or alizarine $[\mathrm{Aliz}]^{2-}$ (4-6). Complexes 1-6 displayed a significant cytotoxic effect on the studied cell line (1.9-52.8 $\mu \mathrm{M} \mathrm{IC}_{50}$ range). For BrCat containing complexes, the biological activity was indipendent of the nature of the coordinated $\left(\mathrm{C}^{\wedge} \mathrm{N}\right)$ ligand. In the case of 4-6 instead, the cytotoxicity (significantly low for 4) was concomintantly induced by the presence of either the PhPy and the $[\mathrm{Aliz}]^{2-}$ ligands. Since complexes 1-6 are emissive in solution, the potential use of complex 4 as theragnostic agent was investigated by confocal analysis. The fluorescence signal from MDA-MB-231 cells incubated with 4 indicated the localization of the compound into the cytosol region.

\section{Introduction}

Owe to the numerous side effects, long term resistance and clinical limitation of the well-known first generation $\mathrm{Pt}(\mathrm{II})$ anticancer complex cisplatin (Chart 1a), ${ }^{1}$ numerous DNA binding platinum drugs have been developed over the years. ${ }^{2,3}$ The so called second generation platinum drugs include $\mathrm{Pt}(\mathrm{II})$ complexes which deviate from the cisplatin template as the metal centre 
experiences a different ligand field, leading to a modulation of the electronic, steric hindrance and

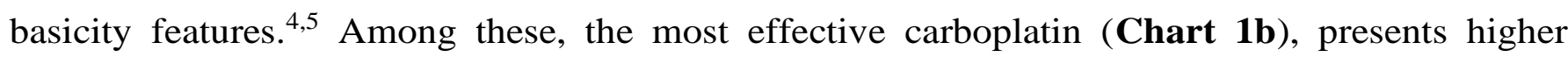
solubility and stability than cisplatin and lower side effects. ${ }^{6}$ The third generation $\mathrm{Pt}(\mathrm{II})$ antitumor drugs, incorporate, instead, different ammines and leaving groups, and among this category emerges as the most popular example, like the water soluble oxaliplatin (Chart 1c), embedding two chelating ligands and exhibiting a broader spectrum of activity than cisplatin or carboplatin. ${ }^{7-9}$ Differently from the mechanism of action of cisplatin and its previously described derivatives, covalently binding $\mathrm{Pt}(\mathrm{II})$ complexes, incorporating a planar aromatic ligand, such as 1,10phenanthroline, anthraquinone, acridine etc., may intercalate between two adjacent DNA base pairs stabilized through $\pi-\pi$ stacking stabilization, ${ }^{10}$ and/or may subsequently coordinately bind to DNA by losing a labile leaving group. ${ }^{11}$ Intercalation causes thus DNA to lose its regular helical structure. ${ }^{14-16}$ As evidenced by a comprehensive study on a series of positively charged $\mathrm{Pt}(\mathrm{II})$ complexes bearing aromatic $\left(\mathrm{N}^{\wedge} \mathrm{N}\right)$ ligands, ${ }^{17-21}$ (Chart 2a-c) the cytotoxicity is influenced by the extension of the aromatic core, as well as by the charge (positive in the examined cases), solubility and effective Pt(II) complex cellular uptake, following a mechanism not yet fully elucidated, but different from the one followed by cisplatin. ${ }^{13,17-18,22-23}$ Several studies have indeed suggested an activity of these Pt(II) complex at a mitochondrial level, while X-ray structures ${ }^{24}$ have demonstrated that the aromatic ligands insert between the base pairs of DNA. ${ }^{25-27}$

Due to their capability of forming repair resistant lethal Pt-DNA crosslinks, bis-chelated Pt(II) complexes have been found more efficient than their counterparts embedding monodentate ligands. ${ }^{13}$ Following such an approach, Mitra et al. synthesized the catecholate containing $\mathrm{Pt}(\mathrm{II})$ neutral complexes $\left[\left(\mathrm{N}^{\wedge} \mathrm{N}\right) \mathrm{Pt}\left(\mathrm{O}^{\wedge} \mathrm{O}\right)\right]^{28}$ (Chart 2 b) based on carboplatin and oxaliplatin archetypes (Chart 1b,c) and by performing time-dependent UV-visible spectral studies they demonstrated the breakage of the Pt-O bond in the presence of an excess of glutathione (GSH), which can be at the basis of the observed activity triggered by the thus generated free owing to the generated free coordinating site.

Regarding the "orphan" tumours, one of the most aggressive is the triple-negative breast cancer (TNBC), which displays evinces a negative response to drugs due to the lack in the main three receptors, common targets of the therapy against breast cancer. ${ }^{29,30}$ Indeed, TNBC does not respond to hormonal therapy medicines or medicines that target HER2 protein receptors. For this reason, it is necessary to introduce a new detecting methodology and treatment for TNBC. In the last years, many research groups have attempted to overcome this limit by focalizing their attention on the development of new therapeutic agents, characterized by the capability to allow a 
targeted imaging together with the induction of a cytotoxic effect in TNBC tumour cells. ${ }^{29,30}$ Taking into consideration this premise, we tested the in vitro biological activity on the MDA-MB231 cell line.

To the best of our knowledge, anionic Pt(II) complexes have never been tested for their biological properties. Herein, we have considered a series of ionic complexes of general formula $\mathrm{NBu}_{4}\left[\left(\mathrm{C}^{\wedge} \mathrm{N}\right) \mathrm{Pt}\left(\mathrm{O}^{\wedge} \mathrm{O}\right)\right]$, featuring the tetrabutylammonium cation and the $\mathrm{Pt}(\mathrm{II})$ organometallic anion $\left[\left(\mathrm{C}^{\wedge} \mathrm{N}\right) \mathrm{Pt}\left(\mathrm{O}^{\wedge} \mathrm{O}\right)\right]$, where $\left(\mathrm{C}^{\wedge} \mathrm{N}\right)$ stands for the cyclometalated form of 2-phenylpyridine $(\mathrm{H}(\mathrm{PhPy}))$, 2-thienylpyridine $(\mathrm{H}(\mathrm{Thpy}))$ or 2-benzo $[h]$ quinoline $(\mathrm{H}(\mathrm{Bzq}))$, while $\left(\mathrm{O}^{\wedge} \mathrm{O}\right)$ represents either the dianion of the tetrabromocatechol $\left(\mathrm{H}_{2}(\mathrm{BrCat}) \text {, (Chart 3, complexes 1-3 }\right)^{31}$ or the dianionic form of the alizarine $\left(\mathrm{H}_{2}(\mathrm{Aliz})\right)$. (Chart 3, complexes 4-6) To complete the series in order to probe the eventual activity of the newly introduced [Aliz] $]^{2-}$ molecular fragment, the neutral complex 7 (Chart 3), parent of the cisplatin archetype, was synthesized and tested. The $\mathrm{Pt}$ (II) complexes were selected taking into account the peculiar molecular structure, ionic in nature, whose anion contains a $\mathrm{Pt}(\mathrm{II})$ centre bonded to a cyclometalated $\left(\mathrm{C}^{\wedge} \mathrm{N}\right)$ ligand $^{32-34}$ and coordinated to a chelating $\left(\mathrm{O}^{\wedge} \mathrm{O}\right)$ fragment. In particular, it has previously been documented that a series of cycloplatinated complexes showed promising $\mathrm{IC}_{50}$ values $(\mu \mathrm{M})$ against Sarcoma 18 cells. ${ }^{35,36}$ Instead, both the $\mathrm{H}_{2}$ (BrCat) and $\mathrm{H}_{2}$ (Aliz) ligands were chosen due to the fact that they may be prone to Pt-O bond breaking in intracellular medium, favouring DNA covalent binding. Finally, compared to $[\mathrm{BrCat}]^{2-}$, the $[\mathrm{Aliz}]^{2-}$ fragment presents a more extended aromatic core combined with a chemical structure similar to those of the already tested antitumor intercalating aromatic molecules doxorubicin (Chart 2e) ${ }^{37-42}$ and mitoxantrone (Chart 2f). ${ }^{43}$

In addition, besides potential anticancer activity, the extended aromatic system and the acidic character of the hydroxyl substituents could confer to the anthraquinone-derived molecule a fluorescent behaviour. ${ }^{44}$ Accordingly, its incorporation into the $\mathrm{Pt}(\mathrm{II})$ complexes is expected to contribute to the development of new compounds as cellular labels or probes for imaging.

\section{Results and discussion}

\section{Synthesis}

The cyclometalated anionic $\mathrm{Pt}(\mathrm{II})$ complexes 1-3 derived from $\mathrm{H}_{2}(\mathrm{BrCat})$ were synthesized as previously reported. ${ }^{33}$ Complexes 4-6 were prepared starting from the respective cycloplatinated precursors I-III (Scheme 1) by adapting an already reported procedure. ${ }^{45}$ Complexes bearing the cyclometalated ligands PhPy (4) and ThPy (5) were prepared starting from a mononuclear intermediate, obtained by microwave assisted synthesis, as previously reported, ${ }^{45}$ while for 
complex 6 incorporating the Bzq fragment, a chloro-bridged binuclear cycloplatinated precursor was used (Scheme 1). ${ }^{46}$ The treatment of I-III with $\mathrm{H}_{2}$ (Aliz) in basic media $\left(\mathrm{NBu}_{4} \mathrm{OH}\right)^{47}$ afforded the anionic square-planar Pt(II) complexes 4-6, in moderate to high yields.

Complex 7 was synthesized starting from cisplatin, which was prepared according to an already described microwave assisted procedure, ${ }^{48}$ followed by treatment with $\mathrm{AgNO}_{3}$ as halogen scavenger and subsequent coordination of [Aliz $]^{2-}$ in basic media (Scheme 2).

The newly synthesized 4-7 complexes were fully characterized by FT-IR and ${ }^{1} \mathrm{H}-,{ }^{13} \mathrm{C}-\mathrm{NMR}$ spectroscopies, ESI-MS, melting points and elemental analysis. Considering the IR spectra of complexes 4-6, the coordination of the $[\mathrm{Aliz}]^{2-}$ group was confirmed by the shift of the $\mathrm{C}=\mathrm{O}$ and C-O stretching bands from $1663 \mathrm{~cm}^{-1}$ and $1460 \mathrm{~cm}^{-1}$, respectively, in the free $\mathrm{H}_{2}$ (Aliz) ligand to ca. 1635 and $c a .1442 \mathrm{~cm}^{-1}$ for complexes 4-6. The C-H aliphatic stretching bands (ca. $2900 \mathrm{~cm}^{-1}$ ) associated to the presence of the $\left[\mathrm{NBu}_{4}\right]^{+}$counterion confirmed the negative charge of the $\mathrm{Pt}(\mathrm{II})$ thus synthesized complexes.

However, due to the asymmetrical structure of the $\mathrm{H}_{2}$ (Aliz) ligand, upon complexation to the $\mathrm{Pt}$ (II) metal centre, two cis/trans geometrical isomers (with respect to the relative position of the $\mathrm{N}$-coordinated atom and the more sterically hindered $\mathrm{O}$-chelated atom) could be expected. ${ }^{32}$ The ${ }^{1} \mathrm{H}-\mathrm{NMR}$ spectra were characterized by the splitting of the signal associated with the proton in alfa position with respect to the cyclometalated nitrogen atom, so accounting for the presence of the two cis/trans isomers that, according to the corresponding signal integration, resulted in 1:0.7 (4), 1:1 (5), 1:1(6) cis/trans ratios. Moreover, the signals associated to the aliphatic protons in the upfield region of the spectrum confirmed the presence of the $\left[\mathrm{NBu}_{4}\right]^{+}$counterion in stoichiometric ratio with respect to the aromatic protons, evidence of the ionic nature of complexes 4-6.

The formation of 4-6 was also confirmed by ${ }^{13} \mathrm{C}-\mathrm{NMR}$ spectroscopy. ESI-MS analyses of complexes, carried out via direct infusion in the negative mode, showed an isotope cluster, centred at $m / z 587.55(4), 593.28(5), 611.68$ (6) due to the natural abundances, and corresponding to the $\left[\left(\mathrm{C}^{\wedge} \mathrm{N}\right) \mathrm{Pt}(\mathrm{Aliz})\right]^{-}$complex anion. The formation of complex 7, instead, was confirmed by the analysis of the FT-IR spectrum, displaying the signal associated to the $\mathrm{NH}_{3}$ groups at 3434 $\mathrm{cm}^{-1}$. Considering the signals relative to the coordinated $[\mathrm{Aliz}]^{2-}$ fragment, the $\mathrm{C}=\mathrm{O}$ and $\mathrm{C}-\mathrm{O}$ stretching are shifted at 1625 and $1490 \mathrm{~cm}^{-1}$, respectively, in complex 7, compared with 1663 and $1460 \mathrm{~cm}^{-1}$ in the free ligand. The ${ }^{1} \mathrm{H}-\mathrm{NMR}$ spectrum is consistent with the chemical structure of complex 7, although showing a broad single signal accounting for both $\mathrm{NH}_{3}$ groups. 


\section{Photophysical properties}

The photophysical properties in solution of 1-3 have been extensively investigated previously. ${ }^{33}$ For a direct comparison, the absorption and emission spectra were re-proposed in the ESI (Figures SI-1,2) and the data summarized in Table 1.

The UV-Vis absorption spectra in DMSO solution of the Aliz series 4-7 are shown in Figure 1. All the cyclometalated complexes 4-6 displayed intense bands in the ultraviolet region between 280 and $330 \mathrm{~nm}$ assigned to the allowed ${ }^{1} \mathrm{LC}\left(\pi-\pi^{*}\right)$ transitions localized respectively on the $\mathrm{PhPy}$, ThPy and Bzq ligand ${ }^{49-51}$ The low-energy absorption bands between 330 and $650 \mathrm{~nm}$ of 4-7 were instead attributed to a mixed (MLCT-LC) character, which predominantly involved the chelating ligand, in agreement with the experimental and theoretical electronic spectra of the Aliz molecule. ${ }^{52,53}$

All the new anionic compounds displayed emissive properties in solution in the red region of the electromagnetic spectrum (Figure 2 and Table 1), showing a structured band arising from the MLCT-LC transition.

\section{Evaluation of in vitro cytotoxic activity}

It has been reported that the $\mathrm{Pt}(\mathrm{II})$ anticancer drug cycloplatam, important for overcoming drug resistance to cisplatin (Chart 4) $)^{54}$ exists under two isomeric cis/trans forms, the biological activity of any single isomeric form remained first unknown, but recently, being still unknown. Recently, the two bioactive isomers have been separated and tested showing equal anticancer activity. ${ }^{55,56}$

For the $\mathrm{NBu}_{4}\left[\left(\mathrm{C}^{\wedge} \mathrm{N}\right) \mathrm{Pt}(\mathrm{Aliz})\right]$ 4-6 complexes, NMR spectroscopy indicate the presence of geometrical isomers. Separation of the two isomers through HPLC, both with chiral and achiral columns under reverse phase conditions, have been attempted but was not successful. Accordingly, in the present study, we preliminary tested the cytotoxic properties of the cis/trans mixture for the 4-6 alizarin containing complexes.

As shown in Table 2, all the complexes exerted a significant cytotoxic effect on triple-negative breast cancer cell line MDA-MB-231, with $\mathrm{IC}_{50}$ values ranging from 1.9 to $127 \mu \mathrm{M}$.

As exhibited by Table 2, all the complexes 1-3 with dianion [BrCat $]^{2-}$ showed a good cytotoxic activity on MDA-MB-231 with values of $\mathrm{IC}_{50}$ around $40 \mu \mathrm{M}$, independently from the ligand used in the complex. On the contrary, when Aliz was used as dianion as in species 4-6, significant differences were evinced in function of the cyclometalated $\left(\mathrm{C}^{\wedge} N\right)$ ligand employed in the 
coordination sphere of the $\mathrm{Pt}(\mathrm{II})$ centre. In particular, the cytotoxic activity of $\mathbf{4}$, in which the PhPy was bound to the $\mathrm{Pt}(\mathrm{II})$, resulted in a very low value of $\mathrm{IC}_{50}$ (IC50 equal to $1.9 \pm 1.6 \mu \mathrm{M}$ ). Complex 4, showed somewhat significant cytotoxic effect on MDA-MB-231 tumour cells compared to normal not transformed vascular smooth muscle cells, showing a ten-fold higher $\mathrm{IC}_{50}$ value $(12.5 \pm 1.0 \mu \mathrm{M} v s 1.9 \pm 1.6 \mu \mathrm{M})$. With the aim to evaluate the capability of $\mathrm{H}_{2}$ (Aliz) ligand to influence alone the cytotoxic activity of a complex, compound 7 was synthetized. The potency of the cytotoxic effect decreased in comparison to cisplatin's value on MDA-MB-231 (IC50 equal to 126.9 $\pm 2.7 \mu \mathrm{M}$ for 7 and $59.4 \mu \mathrm{M}$ for cisplatin). ${ }^{23}$ This data confirmed that the matching between the cyclometalated $\mathrm{H}(\mathrm{PhPy})$ moiety and $[\mathrm{Aliz}]^{2-}$ ligand, in the complexes, was necessary to contribute to cytotoxic activity of the compound. In addition, we evaluated the cytotoxicity effect of ligands utilized for the synthesis of the complexes. As shown in Table 2, BrCat was the only ligand that showed a significant cytotoxic effect with an $\mathrm{IC}_{50}$ value similar to the complexes, while Aliz, ThPy, PhPy and Bzq were inactive. These data suggest a more potent cytotoxic effect of complexes compared to single ligands.

In order to investigate the molecular mechanisms underlying the cytotoxic effect of these complexes, we analysed the effect of $\mathbf{4}$ on cell-cycle progression in MDA-MB-231 cell line. Incubation of MDA-MB-231 with 10\% FCS shows a $15.9 \%$ of cells in S phase (Figure 3). The addition of $5 \mu \mathrm{M}$ of complex 4 to the medium determined an accumulation of cells in $\mathrm{S}$ phase (20.4\%) associated to a concomitant reduction of cells in G2/M phase, from $33.7 \%$ to $22.7 \%$. Taken together, these results indicated that complex 4 exerts an antiproliferative/cytotoxic action by blocking the progression of the cells through the $S$ phase of the cell cycle.

The potential use of complex $\mathbf{4}$ as theragnostic agent was investigated by measuring the fluorescence signal from MDA-MB-231 cells incubated with 2.5 and $5 \mu \mathrm{M}$ concentration of the compound. As shown in Figure 2, we detected a positive signal after $3 \mathrm{~h}$ exposure of the cells with $5 \mu \mathrm{M}$ of complex 4 . Moreover, confocal analysis indicated that the majority of the compound is localized into the cytosol in the perinuclear region (Figure 4).

\section{Conclusions}

A series of cyclometalated anionic complexes of general formula $\mathrm{NBu}_{4}\left[\left(\mathrm{C}^{\wedge} \mathrm{N}\right) \mathrm{Pt}\left(\mathrm{O}^{\wedge} \mathrm{O}\right)\right]$ were synthesized, spectroscopically characterized and tested for their cytotoxicity against MDA-MB-231 triple negative breast cancer cell line. A 2-phenylpyridine $(\mathrm{H}(\mathrm{PhPy}))$, 2-thyenylpyridine $(\mathrm{H}(\mathrm{Thpy}))$ or 2benzo $[h]$ quinoline $(\mathrm{H}(\mathrm{Bzq}))$ were respectively coordinated as $\left(\mathrm{C}^{\wedge} \mathrm{N}\right)$ ligands, while alizarine (Aliz) and tetrabromocatechol (BrCat) were used as a $\left(\mathrm{O}^{\wedge} \mathrm{O}\right)$ chelated ligand. 
The Aliz based complexes $\mathrm{NBu}_{4}\left[\left(\mathrm{C}^{\wedge} \mathrm{N}\right) \mathrm{Pt}(\mathrm{Aliz})\right]$ exhibited an important cytotoxic effect on the studied cell line (1.9-127 $\mu \mathrm{M} \mathrm{IC}_{50}$ range), more efficient compared with the catecholate containing series. By studying the effect of the best performing 4 (with a $\mathrm{IC}_{50}$ of $1.9 \mu \mathrm{M}$ ) onto the MDA-MB-231 cycle progression, it was evidenced that the $\mathrm{Pt}(\mathrm{II})$ species exert an antiproliferative/cytotoxic effect by blocking the progression of the cell cycle in its $\mathrm{S}$ phase.

Since all the investigated complexes are emissive in solution, the most efficient complex $\mathrm{NBu}_{4}[(\mathrm{PhPy}) \mathrm{Pt}(\mathrm{Aliz})]$ was studied by confocal analysis. The fluorescence signal observed from the MDA-MB-231 cells incubated with $\mathrm{NBu}_{4}[(\mathrm{PhPy}) \mathrm{Pt}(\mathrm{Aliz})]$ indicated the presence of the $\mathrm{Pt}(\mathrm{II})$ compound into the cytosol region, for which its potential use as a theragnostic agent could be considered.

\section{Experimental}

\section{General considerations}

All commercially available chemicals were purchased from Sigma Aldrich or Alfa Aesar and were used without further purification. Cycloplatinated precursors I-III and complexes 1-3 were synthesized as already reported. ${ }^{33}$ Microwave assisted syntheses were carried out using a CEM Discover Synthesis Unit (CEM Corp., Matthews, NC). Melting points were determined with a Leica DMLP polarising microscope equipped with a Leica DFC280 camera and a CalCTec (Italy) heating stage. Elemental analyses were performed with a PerkinElmer 2400 analyzer CHNS/O.

\section{Spectroscopy and spectrometry}

IR spectra (KBr pellets) were recorded on a Spectrum One Perkin-Elmer FT-IR spectrometer. ${ }^{1} \mathrm{H}-$ NMR spectra were recorded on a Brucker WH-300 spectrometer in deuterated solvents with TMS as internal standard. MS analyses were performed by using a Thermo Finnigan (MA, USA) LCQ Advantage system MS spectrometer with an electronspray ionisation source and an 'Ion Trap' mass analyser. The MS spectra were obtained by direct infusion of a sample solution in $\mathrm{MeOH}$ under ionisation, ESI negative. Spectrofluorimetric grade DMSO was used for the photophysical investigations in solution, at room temperature. A Perkin Elmer Lambda 900 spectrophotometer was employed to obtain the UV/Vis absorption spectra, using quartz cuvettes of $1 \mathrm{~cm}$ path length. Steady-state emission spectra were recorded on a Horiba Jobin Yvon Fluorolog 3 spectrofluorimeter, equipped with a Hamamatsu R-928 photomultiplier tube. The emission 
quantum yields of 4-7 were obtained using the optical dilution method $^{57}$ using cresyl violet perchlorate in methanol as reference standard $(\Phi=0.54) .{ }^{58}$

\section{Synthesis}

Preparation of $\mathrm{NBu}_{4}\left[(\mathrm{PhPy}) \mathrm{Pt}^{\wedge}\left(\mathrm{O}^{\wedge} \mathbf{O}\right)\right]$ (4). Two equivalents of $\mathrm{H}_{2}$ (Aliz) (22 mg, $\left.0.093 \mathrm{mmol}\right)$ were added to a solution of $\mathbf{I}(50 \mathrm{mg}, 0.093 \mathrm{mmol})$ in $20 \mathrm{ml}$ of degassed ethanol. In this solution, $\mathrm{NBu}_{4} \mathrm{OH}(0.18 \mathrm{ml}, 0.186 \mathrm{mmol})$ was added and the mixture was stirred for 24 hours under reflux. The crude product was concentrated, and water was added. The solid was isolated by filtration and washed with water and diethyl ether. Dark blue solid, yield $61 \%$; m.p. $139{ }^{\circ} \mathrm{C}$; ${ }^{1} \mathrm{H}-\mathrm{NMR}\left(\mathrm{d}_{6^{-}}\right.$ DMSO, $300 \mathrm{MHz}, \mathrm{TMS}) \delta=9.22\left(\mathrm{~d}, \mathrm{~J}_{\mathrm{H}-\mathrm{H}}=5.43 \mathrm{~Hz}, 1 \mathrm{H}\right), 8.96\left(\mathrm{~d}, \mathrm{~J}_{\mathrm{H}-\mathrm{H}}=5.43 \mathrm{~Hz}, 0.7 \mathrm{H}\right), 8.11$ $8.08(\mathrm{~m}, 1 \mathrm{H}), 8.01-7.98(\mathrm{~m}, 2.1 \mathrm{H}), 7.94-7.89(\mathrm{~d}, 0.7 \mathrm{H}), 7.84-7.82(\mathrm{~m}, 3.5 \mathrm{H}), 7.65-7.53(\mathrm{~m}, 6.4 \mathrm{H})$, 7.39-7.36 (m, 2H), 7.30-7.27 (m, 0.7H), 7.18-7.17 (m, 1.3H), 7.05-6.94 (m, 2.7H), 6.51 $\left(\mathrm{d}, \mathrm{J}_{\mathrm{H}-\mathrm{H}}=\right.$ $3.21 \mathrm{~Hz}, 0.7 \mathrm{H}), 6.48\left(\mathrm{~d}, \mathrm{~J}_{\mathrm{H}-\mathrm{H}}=3.06 \mathrm{~Hz}, 1 \mathrm{H}\right), 3.07(\mathrm{~s}, 13.6 \mathrm{H}), 1.47(\mathrm{~s}, 13.6 \mathrm{H}), 1.21(\mathrm{~s}, 13.6 \mathrm{H}), 0.84$ (s, 20.4H); ${ }^{13} \mathrm{C}-\mathrm{NMR}\left(\mathrm{CDCl}_{3}, 300 \mathrm{MHz}, \mathrm{TMS}\right) \delta=182.88,182.78,182.26,181.65,176.75$, $176.65,170.42$, 170.40, 167.39, 167.35, 144.44, 144.20, 144.11, 143.92, 136.74, 136.58, 136.54, $136.30,134.76,134.74,134.67,133.15,132.25,132.12,132.00,131.99,131.64,131.46,130.28$, $129.43,129.34,129.28,126.50,126.44,126.16,126.09,125.92,122.99,122.89,122.60,122.13$, $122.02,121.75,121.50,121.29,119.81,118.81,118.52,118.03,117.80,58.26,23.83,19.42$, 13.53; FT-IR $(\mathrm{KBr}) \vee\left(\mathrm{cm}^{-1}\right)=2959,2931,2872,1633,1511,1443,1339,1301,1281,1257,761$, 721; E.A. calculated (\%) for $\mathrm{C}_{37} \mathrm{H}_{42} \mathrm{~N}_{2} \mathrm{O}_{4} \mathrm{Pt}$ : C, 57.43; H, 5.47; N, 3.62; found: C, 57.83; H, 5.39; $\mathrm{N}, 3.49 ; \mathrm{MS}(\mathrm{ESI}) \mathrm{m} / \mathrm{z} 587.55\left[\mathrm{M}^{-}\right.$

Preparation of NBu4[(ThPy)Pt(Aliz)] (5). Following the same procedure described for the synthesis of 4, the reaction was conducted using II (100 mg, $0.18 \mathrm{mmol}$ ), $\mathrm{H}_{2}$ (Aliz) (43 $\mathrm{mg}, 0.18$ mmol) and $\mathrm{NBu}_{4} \mathrm{OH}(0.40 \mathrm{ml}, 0.36 \mathrm{mmol})$. Dark blue solid, yield $72 \%$; m.p. $108^{\circ} \mathrm{C} ;{ }^{1} \mathrm{H}-\mathrm{NMR}$ $\left(\mathrm{d}_{6}-\mathrm{DMSO}, 300 \mathrm{MHz}, \mathrm{TMS}\right) \delta=9.18(\mathrm{~d}, \mathrm{~J}=5.46 \mathrm{~Hz}, 1 \mathrm{H}), 8.91$ (d, J=5,46 Hz, 1H), 8.18-8.13 (m, $1 \mathrm{H})$, 8.07-8.05 (m, 3H), 7.87-7.82 (m, 1H), 7.72-7.65 (m, 6H), 7.45-7.42 (m, 2H), 7.36-7.34 (m, 1H), 7.28-7.27 (m, 2H), 7.16-7.10 (m, 3H), 7.05-7.02 (m, 2H), $6.60(\mathrm{~d}, 1 \mathrm{H}), 3.14(\mathrm{~s}, 16 \mathrm{H}), 1.54$ $(\mathrm{s}, 16 \mathrm{H}), 1.29(\mathrm{~s}, 16 \mathrm{H}), 0.91(\mathrm{~s}, 24 \mathrm{H}) ;{ }^{13} \mathrm{C}-\mathrm{NMR}\left(\mathrm{CDCl}_{3}, 300 \mathrm{MHz}, \mathrm{TMS}\right) \delta=182.76,182.70$, $182.17,181.67,177.17,173.37,170.89,168.02$, 163.39, 163.29, 150.25, 149.69, 147.99, 147.70, $137.74,137.66,137.39,137.36,136.50,136.23,134.65,134.61,133.41,133.10,132.56,132.20$, $132.09,131.69,131.53,131.38,128.02,127.02,126.48,126.19,126.03,125.93,122.69,121.44$, 
$121.25,119.70,118.81,118.64,117.88,116.72,116.66,116.44,57.82,23.64,19.26,13.46$; FTIR $(\mathrm{KBr}) \vee\left(\mathrm{cm}^{-1}\right)=2959,1635,1601,1513,1475,1444,1257,720$; E.A. calculated $(\%)$ for $\mathrm{C}_{35} \mathrm{H}_{40} \mathrm{~N}_{2} \mathrm{O}_{4} \mathrm{PtS}: \mathrm{C}, 53.90 ; \mathrm{H}, 5.17 ; \mathrm{N}, 3.59$; found: C, 54.15; H, 5.29; N, 3.19; MS (ESI) m/z $593.28\left[\mathrm{M}^{-}\right.$

Preparation of NBu4[(Bzq)Pt(Aliz)] (6). Following the same procedure described for the synthesis of 4, the reaction was conducted using III (100 mg, $0.12 \mathrm{mmol}$ ), $\mathrm{H}_{2}$ (Aliz) (59 $\mathrm{mg}, 0.24$ mmol) and $\mathrm{NBu}_{4} \mathrm{OH}(0.48 \mathrm{ml}, 0.48 \mathrm{mmol})$. Purple solid, yield $55 \%$; m.p. $196{ }^{\circ} \mathrm{C}$; ${ }^{1} \mathrm{H}-\mathrm{NMR}\left(\mathrm{d}_{6^{-}}\right.$ DMSO, $300 \mathrm{MHz}, \mathrm{TMS}) \delta=9.46(\mathrm{~d}, 1 \mathrm{H}), 9.24(\mathrm{~d}, 1 \mathrm{H}), 8.62-8.58(\mathrm{~m}, 2 \mathrm{H}), 8.20-8.18(\mathrm{~m}, 2 \mathrm{H})$, 8.10-8.06 (m, 2H), 7.88-7.83 (m, 2H), 7.76-7.71 (m, 9H), 7.61-7.53 (m, 4H) 7.49-7.45 (m, 2H), 7.39-7.36 (m, 1H), $6.66(\mathrm{~d}, 1 \mathrm{H}), 6.63(\mathrm{~d}, 1 \mathrm{H}), 3.14(\mathrm{~s}, 16 \mathrm{H}), 1.53(\mathrm{~s}, 16 \mathrm{H}), 1.27(\mathrm{~s}, 16 \mathrm{H}), 0.91(\mathrm{~s}$, $24 \mathrm{H}) ;{ }^{13} \mathrm{C}-\mathrm{NMR}\left(\mathrm{CDCl}_{3}, 300 \mathrm{MHz}, \mathrm{TMS}\right) \delta=182.94,182.86,182.82,182.36,182.35,182.34$, 182.32, 182.31, 181.77, 181.74, 181.71, 176.85, 174.13, 174.16 174.10, 175.09, 174.06, 174.03, $168.83,148.95,148.58,148.32,148.29,141.95,141.91,141.08,140.52$, 136.36, 135.54, 135.41, $134.79,134.72,133.29,133.19,132.15,132.02,131.64,131.47,130.92,130.29,129.15,129.03$, $126.56,126.20,126.11,125.96,122.87,121.48,120.90,120.73,119.81,119.63,118.09,116.79$, 57.99, 23.67, 19.21, 13.31; FT-IR $(\mathrm{KBr}) \vee\left(\mathrm{cm}^{-1}\right)=2958,2871,1634,1512,1443,1339,1298$, 1280, 1256, 821, 717; E.A. calculated (\%) for $\mathrm{C}_{39} \mathrm{H}_{42} \mathrm{~N}_{2} \mathrm{O}_{4} \mathrm{Pt}: \mathrm{C}, 58.71 ; \mathrm{H}, 5.31$; N, 3.51; found: C, 58.73; H, 5.25; N, 3.63; MS (ESI) m/z $611.68\left[\mathrm{M}^{-}\right.$

Preparation of $\left[\left(\mathbf{N H}_{3}\right)_{2} \mathbf{P t}(\right.$ Aliz) $]$ (7). Cisplatin $(40 \mathrm{mg}, 0,13 \mathrm{mmol})$ and $\mathrm{AgNO}_{3}(43 \mathrm{mg}, 0,26$ mmol) were suspended in $1 \mathrm{ml}$ of dimethylformamide and stirred at r.t. for $12 \mathrm{~h}$. The precipitated $\mathrm{AgCl}$ was filtered off and to the filtrated solution $\mathrm{H}_{2}$ (Aliz) $(13 \mathrm{mg}, 0,33 \mathrm{mmol})$ and 5 eq. of $\mathrm{NaOH}$ solubilized in $4 \mathrm{~mL}$ of distilled water were added. The reaction mixture was stirred at r.t. for $5 \mathrm{~h}$ under nitrogen atmosphere. The dark solid was filtered, washed with distilled water, ethanol and dichloromethane. Dark blue solid, yield 85\%; m.p. $>250^{\circ} \mathrm{C} .{ }^{1} \mathrm{H}-\mathrm{NMR}\left(\mathrm{d}_{6}\right.$-DMSO, 300 MHz, TMS) $\delta=8.16-8.08(\mathrm{~m}, 2 \mathrm{H}), 7.74-7.72(\mathrm{~m}, 2 \mathrm{H}), 7.43(\mathrm{~d}, \mathrm{~J}=8,46 \mathrm{~Hz}, 1 \mathrm{H}), 6.42(\mathrm{~d}, \mathrm{~J}=8,13$ $\mathrm{Hz}, 1 \mathrm{H}), 3.64(\mathrm{~s}, 6 \mathrm{H})$; FT-IR $(\mathrm{KBr}) v\left(\mathrm{~cm}^{-1}\right)=3434,1626,1490,1384,1286,1208,715$. E.A. calculated (\%) for $\mathrm{C}_{14} \mathrm{H}_{12} \mathrm{~N}_{2} \mathrm{O}_{4} \mathrm{Pt}$ : C, 35.98; H, 2.59; N, 5.99; found: C, 36.03; H, 2.55; N, 5.63. 


\section{Biological studies}

\section{Reagents}

Dulbecco's modified Eagle medium (DMEM), trypsin-EDTA, penicillin/streptomycin, sodium pyruvate, non-essential amino acid solution, fetal calf serum (FCS), plates and Petri dishes were purchased from EuroClone. The compounds were dissolved in dimethyl sulfoxide (DMSO) before performing each experiment. The maximal concentration utilized was $200 \mu \mathrm{M}$; cisplatin was tested up to $100 \mu \mathrm{M}$. The amount of DMSO did not exceed the $0.25 \%$ of the culture media volume.

\section{Cell culture}

Human triple negative cancer cell line MDA-MB-231 were cultured in DMEM supplemented with $10 \%$ FCS, $1 \%$ non-essential amino acids 100X, 1\% penicillin/streptomycin $100 \mathrm{X}, 1 \% \mathrm{~L}-$ glutamine $200 \mathrm{mM}$ and $1 \%$ sodium pyruvate at $37^{\circ} \mathrm{C}$ in a humidified atmosphere $\left(5 \% \mathrm{CO}_{2}\right.$ and $95 \%$ air).

\section{Cell viability assay}

Sulphorhodamine B (SRB) assay was performed to assess the cell viability after treatments. $5 \times 10^{3}$ cells/well were seeded in a 96-well tray in triplicate. After $24 \mathrm{~h}$ of incubation, the cells were treated with different concentrations of compounds. SRB assay were performed after $48 \mathrm{~h}$ as previously described. ${ }^{24}$

\section{Confocal microscopy analysis}

$4 \times 10^{4}$ cells/well were seeded in a 24 -well tray in duplicate. After $24 \mathrm{~h}$ of incubation, the cells were treated with 2.5 and $5 \mu \mathrm{M}$ of complex 4. After $3 \mathrm{~h}$ of incubation, the cells were washed with PBS, fixed with paraformaldehyde (PFA) $4 \%$ at r.t. for $10 \mathrm{~min}$. After fixation, free aldehyde groups were removed by incubate the cells with $\mathrm{NH}_{4} \mathrm{Cl} 50 \mathrm{mM}$ for $10 \mathrm{~min}$ at r.t.. Finally, the cells were washed three times with PBS and stored in PBS at $4{ }^{\circ} \mathrm{C}$ until the confocal analysis.

The confocal microscopy analysis has been performed with Zeiss LSM 800 by exciting the cells with $\lambda=405 \mathrm{~nm}$. Fluorescence has been collected at $\lambda=590-670 \mathrm{~nm}$.

\section{Statistical analysis}

Experimental data are expressed as mean \pm S.D. The effects of the complexes versus control were analysed by two-tailed Student's t test for unpaired data. The concentration of compounds 
required to reduce by $50 \%$ of cell viability $\left(\mathrm{IC}_{50}\right)$ was calculated by 4-PL nonlinear regression curve (GraphPad Prism, Version 5.01).

\section{Conflicts of interest}

There are no conflicts to declare.

\section{Acknowledgements}

A.I. and I.A. are grateful to Kevin Donato for his contribution during the preparation of selected complexes.

\section{References}

[1] V. Brabec, O. Hrabina, J. Kasparcova, Coord. Chem. Rev. 2017, 351, 2.

[2] E. Alessio, Z. Guo, Eur. J. Inorg. Chem. 2017, 1539.

[3] B. J. Pages, K. B. Garbutcheon-Singh, J. R. Aldrich-Wright, Eur. J. Inorg. Chem. 2017, 1613.

[4] K. S. Lovejoy, R. C. Todd, S. Zhang, M.S. McCormick, J. A. D’Aquino, J. T. Reardon, A. Sancar, K. M. Giacomini, S. J. Lippard, Proc. Natl. Acad. Sci. USA 2008, 105, 8902.

[5] A. P. Silverman, W. Bu, S. M. Cohen, S. J. Lippard, J. Biol. Chem. 2002, 277, 49743.

[6] M. J. Cleare, J. D. Hoeschele, Bioinorg. Chem. 1973, 2, 187.

[7] J. L. Misset, H. Bleiberg, W. Sutherland, M. Bekradda, E. Cvitkovic, Crit. Rev. Oncol. Hemat. 2000, 35, 75 .

[8] F. Levi, G. Metzger, C. Massari, G. Milano, Clin. Pharmacokinet. 2000, 38, 1.

[9] G. Facchetti, I. Rimoldi, Bioorg. Med. Chem. Lett. 2019, 29, 1257.

[10] K. M. Deo, D. L. Ang, B. McGhie, A. Rajamanickam, A. Dhiman, A. Khoury, J. Holland, A. Bjelosevic, B. Pages, C. Gordon, J. R. Aldrich-Wright, Coord. Chem. Rev. 2018, 375, 148.

[11] N. J. Wheate, C. R. Brodie, G. Collins, S. Kemp, J. R. Aldrich-Wright, Mini-Rev. Med. Chem. 2007, 7, 627.

[12] R. C. Harrison, A. McAuliffe, A. M. Zaki, Inorg. Chim. Acta 1980, 46, L15.

[13] M. Tiziano, A. Pratesi, D. Cirri, S. Pillozzi, G. Petroni, A. Guerri, A. Arcangeli, L. Messori, G. Gabbiani, Inorg. Chim. Acta 2018, 470, 318.

[14] W. D. Wilson, R. L. Jones, Adv. Pharmacol. Chemother. 1981, 18, 177.

[15] M. H. Werner, A. M. Gronenborn, G. M. Clore, Science 1996, 271, 778.

[16] P. Lincoln, B. Norden, J. Phys. Chem. B 1998, 102, 9583.

[17] C. R. Brodie, J. G. Collins, J. R. Aldrich-Wright, Dalton Trans. 2004, 1145. 
[18] A. M. Krause-Heuer, R. Grünert, S. Kühne, M. Buczkowska, N. J. Wheate, D. D. Le Pevelen, L. R. Boang, D. M. Fisher, J. Kasparkova, J. Malina, P. J. Bednarski, V. Brabek, J. R. AldrichWright, J. Med. Chem. 2009, 52, 5474.

[19] B. J. Pages, J. Sakoff, J. Gilbert, A. Rodger, N. P. Chmel, N. C. Jones, S. M. Kelly, D. L. Ang, J. R. Aldrich-Wright, Chem. Eur. J. 2016, 22, 8943.

[20] D. Jaramillo, D. P. Buck, J. G. Collins, R. R. Fenton, F. H. Stootman, N. J. Wheate, J. R. Aldrich-Wright, Eur. J. Inorg. Chem. 2006, 839.

[21] B. J. Pages, J. Sakoff, J. Gilbert, Y. Zhang, F. Li, D. Preston, J. D. Crowley, J. R. AldrichWright, J. Inorg. Biochem. 2016, 165, 92.

[22] I. Rimoldi, G. Facchetti, G. Lucchini, E. Castiglioni, S. Marchianò, N. Ferri, Bioorg. Med. Chem. 2017, 25, 1907.

[23] I. Rimoldi, V. Coccè, G. Facchetti, G. Alessandri, A. T. Brini, F. Sisto, E. Parati, L. Cavicchini, G. Lucchini, F. Petrella, E. Ciusani, A. Pessina, Biomed. Pharmacother. 2018, 108, 111.

[24] K. J. Garbutcheon-Singh, P. Leverett, S. Myers and J. R. Aldrich-Wright, Dalton Trans. 2013, $42,918$.

[25] K. J. Garbutcheon-Singh, S. Myers, B. W. J. Harper, N. S. Ng, Q. Dong, C. Xie, J. R. AldrichWright, Metallomics 2013, 5, 1061.

[26] C. M. Nunn, L. Van Meervelt, S. Zhang, M. H. Moore, O. Kennard, J. Mol. Biol. 1991, 222, 167.

[27] K. W. Jennette, J. T. Gill, J. A. Sadownick, S. J. Lippard, J. Am. Chem. Soc. 1976, 98, 6159.

[28] K. Mitra, S. Patil, P. Kondaiah, A. K. Chakravarty, Inorg. Chem. 2015, 54, 253.

[29] J. Guorui, R. He, Q. Liu, Y. Dong, M. Lin, W. Li, F. Xu, ACS Appl. Mater. Interfaces 2018, 10, 10634.

[30] A. Pawar, P. Prabhu, Biomed. Pharmacother. 2019, 110, 319.

[31] K. Mitra, S. Gautam, P. Kondaiah and A. R. Chavravarty, Chem. Med. Chem. 2016, 11, 1956.

[32] A. Ionescu, N. Godbert, L. Ricciardi, M. La Deda, I. Aiello, M. Ghedini, I. Rimoldi, E. Cesarotti, G. Facchetti, G. Mazzeo, G. Longhi, S. Abbate, M. Fusè, Inorg. Chim. Acta 2017, $461,267$.

[33] L. Ricciardi, M. La Deda, A. Ionescu, N. Godbert, I. Aiello, M. Ghedini, Dalton Trans. 2017, $46,12625$.

[34] A. Ionescu, N. Godbert, I. Aiello, L. Ricciardi, M. La Deda, A. Crispini, $\quad$ E. Sicilia, M. Ghedini, Dalton Trans. 2018, 47, 11645. 
[35] A. Zamora, S. A. Pérez, V. Rodríguez, C. Janiak, G. S. Yellol, J. Ruiz, J. Med. Chem. 2015, 58, 1320.

[36] T. Okada, I. M. El-Mehasseb, M. Kodaka, T. Tomohiro, K. Okamoto, H. Okuno, J. Med. Chem. 2001, 44, 4661 .

[37] G. A. Leonard, T. W. Hambley, K. McAuley-Hecht, T. Brown and W. N. Hunter, Acta Cryst. D 1993, 49, 458.

[38] T. W. Plumbridge, V. Knight, K. L. Patel, J. R. Brown, J. Pharm. Pharmacol. 1980, 32, 78.

[39] P. De Isabella, G. Capranico, M. Palumbo, C. Sissi, A. P. Krapcho, F. Zunino, Mol. Pharmacol. 1993, $45,715$.

[40] C. Asche, Mini-rev. Med. Chem. 2005, 5, 449.

[41] J. Kapucinski, Z. Darzynkiewcz, Biochem. Pharmacol. 1985, 34, 4203.

[42] G. A Leonard, T. M. Hambley, K. McAuley-Hecht, T. Brown, W. N. Hunter, Acta Crystallogr. Sect. D: Biol. Crystallogr. 1993, 49, 458.

[43] M. Palumbo, B. Gatto, S. Moro, C. Sissi, G. Zagotto, Biochem. Biophys. Acta Mol. Basis Dis. 2002, 1587, 145.

[44] C. Grazia, C. Clementi, C. Milianic, A. Romani, Photochem. Photobiol. Sci. 2011, 10, 1249.

[45] N. Godbert, T. Pugliese, I. Aiello, A. Bellusci, A. Crispini, M. Ghedini, Eur. J. Inorg. Chem. 2007, 5105.

[46] A. Ionescu, L. Ricciardi, Inorg. Chim. Acta 2017, 460, 165.

[47] E. I. Szerb, A. Ionescu, N. Godbert, Y. J. Yadav, A. M. Talarico, M. Ghedini, Inorg. Chem. Comm. 2013, 37, 80.

[48] E. Petruzzella, C. V. Chirosca, C. S. Heidenga, J. D. Hoeschele, Dalton Trans. 2015, 44, 3384.

[49] A. Diez, J. Fornies, C. Larraz, E. Lalinde, J. A. Lopez, A. Martin, M. T. Moreno, V. Sicilia, Inorg. Chem. 2010, 49, 3239.

[50] F. Julìa, P. C. Jones, P. Gonzalez-Herrero, Inorg. Chem. 2012, 51, 5037.

[51] K. P. Balshev, M. V. Puzyk, V. S. Kotlyar, M. V. Kulikova, Coord. Chem. Rev. 1997, 159, 109.

[52] A. Amat, C. Miliani, A. Romanic, S. Fantacci, Phys.Chem.Chem.Phys.2015, 17, 6374.

[53] L. Carta, M. Biczysko, J. Bloino, D. Licaria, V. Barone, Phys.Chem.Chem.Phys. 2014, 16, 2897.

[54] M. Drees, W. M. Dengler, H. R. Hendriks, L. R. Kelland, H. H. Fiebig, Eur. J. Cancer 1995, $31,356$.

[55] W. Liu, J. Su, J. Jiang, X. Li, Q. Ye, H. Zhou, J. Chen, Y. Li., Scientific Rep 2013, 3, 2464.

[56] J. Jiang, J. Qiu, L. Lou, A. Gao, S. Hou, W. Liu, Res. Chem. Intermediat. 2018, 44, 6479. 
[57] J. N. Demas, G. A. Crosby, J. Phys. Chem. 1971, 75, 991.

[58] D. Magde, J. H. Brannon, T. L. Cremers, J. Olmsted, J. Chem. Phys. 1979, 83, 696. 
Table 1. Photophysical data of compounds 1-7 in DMSO solution $\left(1 \cdot 10^{-5} \mathrm{M}\right)$ at $298 \mathrm{~K}$.

\begin{tabular}{|c|c|c|c|}
\hline Complex & $\begin{array}{l}\text { Absorption } \lambda_{\max } / \mathrm{nm} \\
\left(\varepsilon / \mathrm{M}^{-1} \mathrm{~cm}^{-1}\right)\end{array}$ & $\begin{array}{l}\text { Emission } \\
\lambda_{\max } / \mathrm{nm}\end{array}$ & $\Phi(\%)$ \\
\hline $\mathbf{1}^{a}$ & $\begin{array}{c}\text { 293(21072)-314(13937)-328(11313)-417(sh)- } \\
442(9324)\end{array}$ & 593 & 0.02 \\
\hline $2^{a}$ & $309(27950)-349(\mathrm{sh})-421(10075)-448(10303)$ & $581,606,529$ & 0.19 \\
\hline $\mathbf{3}^{b}$ & $\begin{array}{c}\text { 319(21070)-354(11237)-378(10444)-430(sh)- } \\
464(9141)\end{array}$ & 621 & 0.04 \\
\hline 4 & $\begin{array}{c}\text { 287(32152)-422(5248)-535(sh)-571(11707)- } \\
612(\mathrm{sh})\end{array}$ & $670,725,790(\mathrm{sh})$ & 0.40 \\
\hline 5 & $\begin{array}{c}\text { 295(27715)-347(sh)-423(7221)-532(sh)- } \\
569(13975)-609(\mathrm{sh})\end{array}$ & $670,725,790(\mathrm{sh})$ & 0.25 \\
\hline 6 & $\begin{array}{c}\text { 278(28036)-321(sh)-360(8281)-436(sh)- } \\
532(\mathrm{sh})-571(15800)-612(\mathrm{sh})\end{array}$ & $670,725,790(\mathrm{sh})$ & 0.31 \\
\hline 7 & $357(5770)-421(\mathrm{sh})-480(\mathrm{sh})-557(4178)$ & 670,780 & 0.20 \\
\hline
\end{tabular}

${ }^{a}$ Complex 1-3 are reproduced from ref. 33 . 
Table 2. Cytotoxicity effect of anionic Pt(II) complexes 1-7 and their ligands on MDA-MB-231 cell line.

N.A.: not active

\begin{tabular}{ll}
\hline Complex & $\mathrm{IC}_{50}(\mu \mathrm{M})$ \\
\hline $\mathbf{1}$ & $52.8 \pm 3.9$ \\
$\mathbf{2}$ & $46.1 \pm 3.1$ \\
$\mathbf{3}$ & $31.7 \pm 0.6$ \\
$\mathbf{4}$ & $1.9 \pm 1.6$ \\
$\mathbf{5}$ & $18.3 \pm 2.3$ \\
$\mathbf{6}$ & $6.8 \pm 0.6$ \\
$\mathbf{7}$ & $126.9 \pm 2.7$ \\
$\mathbf{A l i z}$ & N.A. \\
BrCat & $32.7 \pm 7.3$ \\
ThPy & N.A. \\
PhPy & N.A. \\
Bzq & N.A.
\end{tabular}

